\title{
Design and synthesis of novel 4-aminophenazone Schiff bases by grinding technique as prospective anti-inflammatory agents
}

\author{
Rashmi Arora, Rishi Sharma, Abhishek Tageza, Ajmer Singh Grewal, Balraj Saini, Sandeep Arora, Rajwinder Kaur* \\ Chitkara College of Pharmacy, Chitakara University, Punjab, India.
}

\section{ARTICLE INFO \\ Received on: 30/11/2019 \\ Accepted on: 09/07/2020 \\ Available online: 25/02/2021}

Key words:

4-Aminophenazone, anti-

inflammatory, docking,

PDE7, Schiff bases.

\begin{abstract}
Schiff bases are biologically diverse molecules with vast pharmacological activities and have been an area of interest in medicinal chemistry. Recently, this class also attributed new targets for drug development and research. The present study reveals the design and synthesis of the novel Schiff bases as prospective anti-inflammatory agents from the combination of 4-aminopyrazone with different aldehydes with a simple and effective grinding technique to produce different yellow-shaded products. The compounds formed were analyzed by IR spectra and ${ }^{1} \mathrm{H}$-nuclear magnetic resonance. Synthesized derivatives were evaluated in silico using docking studies to predict phosphodiesterase 7 (PDE7) inhibition and to investigate the binding interactions of the synthesized derivatives with active site residues of PDE7. These compounds showed appreciable binding interactions with PDE7 protein and good drug-like properties.
\end{abstract}

\section{INTRODUCTION}

Innovation of potent and newer analogs of molecules with already established activities form a research key in the pharamaceutical field. Biological activities of various organic molecules are characterized by their structural attributes which result in certain activities of the parent molecule while others are the result of the associated type, orientation type, and of additives modification. Bringing about modification by manipulating the basic compound structures serves to enhance the activity of the compound and also removes toxicity associated with a basic structure (Cunha et al., 2005; Jawher et al., 2011; Mohanram and Meshram, 2014).

Prostaglandins and various inflammation mediators can cause pyrexia and pain in the body. Nonsteroidal antiinflammatory drugs (NSAIDs) can effectively block the synthesis of these mediators. Ancient history has proved them to be as major therapeutic potentials for their use in the commercial market and clinical practice. NSAIDs are used for the treatment of diseases like gout, arthritis, and asthma (Rainsford, 2007). As

Abstract of this article was presented at CUDC consortium and Summer School Conference at Chitkara University, India.

*Corresponding Author

Rajwinder Kaur, Chitkara College of Pharmacy, Chitakara University, Punjab, India.Email: rajwinder.kaur@chitkara.edu.in they cause nonselective inhibition of both Cyclooxygenase (COX1) and COX-2 isoforms of the cyclooxygenase enzymes, their long-term administration leads to renal disorders,bleeding, and gastrointestinal ulcers (Hörl, 2010).

Alternatives to NSAIDs are being searched for all over the world so that newly designed anti-inflammatory drugs are without varied side effects. The inhibition of phosphodiesterase 7 (PDE7) results in elevated Cyclic adenosine monophosphate (cAMP) levels leading to a decrease in edema, cellular inflammation, and bronchoconstriction, as well as the release of mucous. The effectiveness of the inhibitors of PDE7 enzyme has been reported recently in animal models as anti-inflammatory agents and denotes as a novel category of drugs for the management of various inflammatory diseases (Gil et al., 2008; Grewal et al., 2017a). Due to the emerging need of improved analogs, various heterocyclic compounds are synthesized, including pyrazole compounds and their derivatives as PDE7 inhibitors (Redondo et al., 2012). 4-Aminoantipyrine could be used as a backbone for the synthesis of pyrazolone analogs having various vital pharmacological activities. 4-Aminoantipyrines are the best known antipyrine derivatives indicated to be used in oxidative stress and also have prophylaxis in the diseases like cancer have many other medical implementations (Barnes et al., 2001; et al., 2004). 
The largest number of heterocyclic compounds are of synthetic origin, although few have also been obtained from natural resources like antibiotics, vitamins, cardiac glycoside, and alkaloids. Nowadays, chemists are paying attention to Schiff bases to discover new drugs with very few side effects, as they indicate a wide range of biological activities, which have a proved structure activity relationship of these bases (Vergne et al., 2004).

Recently, various methods have been Schiff basecontaining derivatives that have been synthesized and evaluated for their biological activities, such as antimicrobial, anti-tuberculosis, antioxidant, anti-inflammatory, anticonvulsants, antidepressant, anxiolytic, antihypertensive, anticancer, and antifungal activities. The search for Schiff base-containing compounds with more selective activity and lower side effects continues to be an active area of argument examination in medicinal chemistry (Aboul-Fadl and Bin-Jubair 2010; Alam et al., 2012; da Silva et al., 2011; Gaber et al., 2018; Malik et al., 2018; Murtaza et al., 2017; Rakesh et al., 2015; Sondhi et al., 2006).

Various methods have been used for the synthesis of derivatives of Schiff bases (Akhter et al., 2017; Al Zoubi et al., 2016). The present paper deals with the synthesis of Schiff bases of 4-aminopyrazone by using grinding technique, followed by docking studies with PDE7 and evaluating them in future for antiinflammatory and analgesic activities.

\section{MATERIALS AND METHODS}

\section{Chemicals}

4-Aminoantipyrine was obtained from $\mathrm{CDH}$ Ltd. (New Delhi, India) and other reagents were procured from Loba Chem, Merck Ltd., and SD Fine. The progress of the reaction was monitored by precoated silica gel plates $60 \mathrm{~F}_{254}$ (Merck). Melting points $\left({ }^{\circ} \mathrm{C}\right)$ were determined with a LABINDIA melting point apparatus and were uncorrected. Fourier-transform infrared spectroscopy (FTIR) spectra were recorded on Bruker FT-IR spectrometer by using $\mathrm{KBr}$ disks at Chitkara College of Pharmacy. The ${ }^{1} \mathrm{H}$-nuclear magnetic resonance (NMR) spectra were recorded on Bruker Avance II 400 Spectrometer$400 \mathrm{MHz}$ in $\mathrm{CDCl}_{3}$ using TMS as an internal standard at Panjab University, Chandigarh.

\section{General synthesis}

A mixture of 4-aminophenazone (1) $(0.01 \mathrm{moL})$ and different aldehydes (2) (0.02 moL) were ground in a pestle mortar; the mixture turned pasty after a few minutes of grinding. The grinding continued until a yellow product appeared. The mixture was left overnight. The synthesized compounds (S1S6) were recrystallized from ethanol. The reaction completion was monitored by Thin Layer Chromatography (TLC).

4-(4-Bromobenzylideneamino)-1,5-dimethyl-2-phenyl-1,2dihydropyrazol-3-one (S1)

${ }^{1} \mathrm{H}$ NMR $\left(\mathrm{CDCl}_{3}\right): 2.5006\left(s, 3 \mathrm{H},-\mathrm{CH}_{3}\right), 3.1625(\mathrm{~s}$, $\left.3 \mathrm{H},-\mathrm{NCH}_{3}\right), 7.4475-7.4295(m, 5 \mathrm{H}, \mathrm{Ar}-\mathrm{H}), 7.5193-7.5402$ $(d, 2 \mathrm{H}, \mathrm{Ar}-\mathrm{H}, J=8.4), 7.7066-7.7276(d, 2 \mathrm{H}, \mathrm{Ar}-\mathrm{H}, J=8.4)$, $9.7021(s, 1 \mathrm{H}, \mathrm{N}=\mathrm{CH})$; IR cm ${ }^{-1}: 1,073(\mathrm{Ar}-\mathrm{Br} ; \mathrm{str}), 1,370$ and $1,462\left(-\mathrm{CH}_{3} ; \mathrm{CH}\right.$ bend $), 1,640(\mathrm{C}=\mathrm{N} ; \mathrm{str}), 2,856-2,973(\mathrm{Ar}-$ $\mathrm{CH}$; str).
4-(4-Hydroxybenzylideneamino)-1,5-dimethyl-2-phenyl-1,2dihydropyrazol-3-one (S2)

${ }^{1} \mathrm{H}$ NMR $\left(\mathrm{CDCl}_{3}\right): 2.4919\left(s, 3 \mathrm{H},-\mathrm{CH}_{3}\right), 3.2028(s$, $\left.3 \mathrm{H},-\mathrm{NCH}_{3}\right), 6.8180-6.7968(d, 2 \mathrm{H}, \mathrm{Ar}-\mathrm{H}, J=8.48), 7.3406-$ 7.3753 ( $m, 3 \mathrm{H}, \mathrm{Ar}-\mathrm{H}), 7.4281-7.4368(d, 2 \mathrm{H}, \mathrm{Ar}-\mathrm{H}, J=3.48)$, 7.6375-7.6163 ( $d, 2 \mathrm{H}, \mathrm{Ar}-\mathrm{H}, J=8.48), 8.7534(b s, 1 \mathrm{H},-\mathrm{OH})$, $9.5886(s, 1 \mathrm{H}, \mathrm{N}=\mathrm{CH})$; IR cm ${ }^{-1}: 1,290$ (C-O; str), 1,420 and 1,458 (-CH3; $\mathrm{CH}$ bend), 1,651 (C=N; str), 2,934-2,972 (Ar$\mathrm{CH}$; str), 3,420 (-OH; str).

4-(4-Nitrobenzylideneamino)-1,5-dimethyl-2-phenyl-1,2dihydropyrazol-3-one (S3)

${ }^{1} \mathrm{H} \mathrm{NMR}\left(\mathrm{CDCl}_{3}\right): 2.5291\left(s, 3 \mathrm{H},-\mathrm{CH}_{3}\right), 3.2421(s, 3 \mathrm{H}$, $\left.-\mathrm{NCH}_{3}\right), 7.3497-7.3990$ ( $\left.m, 3 \mathrm{H}, \mathrm{Ar}-\mathrm{H}\right), 7.4863-7.4907(m, 2 \mathrm{H}$, Ar-H), 7.9676-7.9896 ( $d, 2 \mathrm{H}, \mathrm{Ar}-\mathrm{H}, J=8.8), 8.2401-8.2620$ $(d, 2 \mathrm{H}, \mathrm{Ar}-\mathrm{H}, J=8.76), 9.7915(s, 1 \mathrm{H}, \mathrm{N}=\mathrm{CH}) ; \mathrm{IR} \mathrm{cm}^{-1}: 1,345$ and 1,552 (Ar-NO2; str), 1,418 and 1,460 (-CH3; $\mathrm{CH}$ bend), 1,642 (C=N; str), 2,851-2,926 (Ar-CH; str), 3,075-3,107 (CH; str Ar-NO2; str).

4-(3,4,5-Trimethoxybenzylideneamino)-1,5-dimethyl-2-phenyl1,2-dihydropyrazol-3-one (S4)

${ }^{1} \mathrm{H}$ NMR $\left(\mathrm{CDCl}_{3}\right): 2.4979\left(s, 3 \mathrm{H},-\mathrm{CH}_{3}\right), 3.1592(s$, $\left.3 \mathrm{H},-\mathrm{NCH}_{3}\right), 3.8909\left(s, 3 \mathrm{H},-\mathrm{OCH}_{3}\right), 3.9202\left(s, 6 \mathrm{H},-\mathrm{OCH}_{3}\right)$, 7.1234 ( $s, 2 \mathrm{H}, \mathrm{Ar}-\mathrm{H}), 7.4013-7.4258$ ( $m, 2 \mathrm{H}, \mathrm{Ar}-\mathrm{H}), 7.4659$ $7.5047(m, 3 \mathrm{H}, \mathrm{Ar}-\mathrm{H}), 9.6862(s, 1 \mathrm{H}, \mathrm{N}=\mathrm{CH})$; IR cm ${ }^{-1}: 1,234$ (Ar-C-O; str), 1,393 and 1,464 $\left(-\mathrm{CH}_{3}\right.$; $\mathrm{CH}$ bend), 1,647 $(\mathrm{C}=\mathrm{N}$; str), 2,846-2,942 (Ar-CH; str).

1,5-Dimethyl-4-((5-nitrofuran-2-yl)methyleneamino)-2-phenyl1,2-dihydropyrazol-3-one (S5)

${ }^{1} \mathrm{H} \mathrm{NMR}\left(\mathrm{CDCl}_{3}\right): 2.5186\left(s, 3 \mathrm{H},-\mathrm{CH}_{3}\right), 3.2605(s, 3 \mathrm{H}$, - $\left.\mathrm{NCH}_{3}\right), 6.9239-6.9334(d, 1 \mathrm{H},-\mathrm{ArH}), 7.3753-7.3996(m, 3 \mathrm{H}$, Ar-H), 7.4896-7.5283 (m, 3H, Ar-H), 9.8619 ( $s, 1 \mathrm{H}, \mathrm{N}=\mathrm{CH})$; IR cm ${ }^{-1}: 1,365$ and $1,467\left(-\mathrm{CH}_{3} ; \mathrm{CH}\right.$ bend $), 1,642(\mathrm{C}=\mathrm{N}$; str $)$, 2,944-3,150 (Ar-CH; str).

4-(3,4-Dimethoxybenzylideneamino)-1,5-dimethyl-2-phenyl-1,2dihydropyrazol-3-one (S6)

${ }^{1} \mathrm{H} \mathrm{NMR}\left(\mathrm{CDCl}_{3}\right): 2.4856\left(s, 3 \mathrm{H},-\mathrm{CH}_{3}\right), 3.1317(s$, $\left.3 \mathrm{H},-\mathrm{NCH}_{3}\right), 3.9182\left(s, 3 \mathrm{H},-\mathrm{OCH}_{3}\right), 3.9426\left(s, 3 \mathrm{H},-\mathrm{OCH}_{3}\right)$, 6.9684-6.9888 (d, 1H, Ar-H, $J=8.16), 7.3013-7.3268(m, 1 \mathrm{H}$, Ar-H), 7.4003-7.4249 ( $m, 3 \mathrm{H}, \mathrm{Ar}-\mathrm{H}), 7.4536-7.4688$ ( $m, 2 \mathrm{H}$, Ar-H), 7.5481-7.5525 m, 1H, Ar-H), 9.6945 ( $s, 1 \mathrm{H}, \mathrm{N}=\mathrm{CH})$; IR $\mathrm{cm}^{-1}$ : 1,268 (Ar-C-O; str), 1,364 and 1,461 (-CH3; $\mathrm{CH}$ bend), 1,646 (C=N; str), 2,841-3,081 (Ar-CH; str).

\section{In silico prediction of pharmacokinetic parameters}

All the synthesized molecules were analyzed for the prediction of pharmacokinetic parameters related to absorption, distribution, metabolism, and excretion (ADME) by employing FAF-Drugs4 online server; and accessed using 'Lipinski's rule of 5" for drug-likeness (Lagorce et al., 2017).

\section{Molecular docking studies}

Docking studies were carried out for the synthesized compounds with PDE7 protein using AutoDock Vina (Trott and Olson, 2010) and the graphical user interface, AutoDock Tools 
(ADT) (Morris et al., 2009). 2D chemical structures of the ligands were drawn using Marvin Sketch (ChemAxon. Ltd. Budapest, Hungary) and converted to 3D using Frog2 (Miteva et al., 2010) server, followed by thepreparation of PDBQT files using ADT. The co-crystallized information about PDE7 was taken from the protein data bank. After evaluating the number of entries, the best ligand bound complex (PDB entry: 4PM0) was selected based on maximum resolution. The PDB file of the protein was edited and the complexed inhibitor, all the water molecules as well as all non-interacting ions, were removed using PyMOL (Schrödinger, LLC). PDBQT file of protein from PDB file was generated using ADT. All the polar hydrogen atoms were added to the protein molecule and grid parameters were calculated utilizing "Grid" in ADT. The accuracy of docking procedure was checked by docking of the reference inhibitors in the active sites of PDE7. The optimized ligands were docked into the active site of the refined PDE7 models using AutoDock Vina and scored using scoring functions (Charaya et al., 2018; Grewal et al., 2017b; Sharma et al., 2019).

\section{RESULT AND DISCUSSION}

\section{Chemistry}

The designed molecules 4-aminopyrazone Schiff bases (S1-S6) were synthesized (Figure 1) starting from 4-aminophenazone (1) and different aldehydes (2). Physiochemical data of 4-aminophenazone Schiff bases are given in Table 1.

The disappearance of a primary amino group $\left(-\mathrm{NH}_{2}\right)$ stretch and appearance of absorption band at 1,640-1,650 $\mathrm{cm}^{-1}$ related to the $v(\mathrm{C}=\mathrm{N})$ stretch of the Schiff base in the FTIR spectra of synthesized compounds indicates the synthesis of desired compounds. Furthermore, a prominent singlet signal of $\mathrm{N}=\mathrm{Cat} \delta 9.58-9.86 \mathrm{ppm}$ in the ${ }^{1} \mathrm{H}$ NMR spectra confirmed the formation of title compounds (S1-S6) (Table 2).

\section{Prediction of ADME properties}

ADME parameters, including molecular weight (MW), partition coefficient $(\log \mathrm{P})$, distribution coefficient<smiles>Cc1c(N)c(=O)n(-c2ccccc2)n1C</smiles>

1

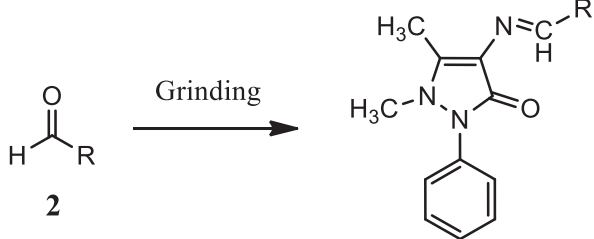

S1-S6

Figure 1. Synthesis of the novel series of 4-aminophenazone Schiff bases.

Table 1. Physiochemical parameters of Schiff bases of 4-aminophenazone (S1-S6).

\begin{tabular}{|c|c|c|c|c|c|}
\hline Comp. & $\mathbf{R}$ & Molecular formula & $\%$ Yield & M. pt. $\left({ }^{\circ} \mathrm{C}\right)$ & $R_{\mathrm{f}}^{\mathrm{a}}$ \\
\hline S1 & & $\mathrm{C}_{18} \mathrm{H}_{16} \mathrm{BrN}_{3} \mathrm{O}$ & 78 & $127-128$ & 0.57 \\
\hline S2 & & $\mathrm{C}_{18} \mathrm{H}_{17} \mathrm{~N}_{3} \mathrm{O}_{2}$ & 75 & 135-136 & 0.62 \\
\hline S3 & & $\mathrm{C}_{18} \mathrm{H}_{16} \mathrm{~N}_{4} \mathrm{O}_{3}$ & 72 & 130-132 & 0.54 \\
\hline S4 & & $\mathrm{C}_{21} \mathrm{H}_{23} \mathrm{~N}_{3} \mathrm{O}_{4}$ & 80 & $122-124$ & 0.60 \\
\hline S5 & & $\mathrm{C}_{16} \mathrm{H}_{14} \mathrm{~N}_{4} \mathrm{O}_{4}$ & 75 & $132-133$ & 0.48 \\
\hline S6 & & $\mathrm{C}_{20} \mathrm{H}_{21} \mathrm{~N}_{3} \mathrm{O}_{3}$ & 80 & $121-122$ & 0.58 \\
\hline
\end{tabular}

aTLC Solvent: Chloroform: methanol (8:2). 
( $\log$ D), water solubility (log Sw), topological polar surface area (tPSA), hydrogen bond acceptors (HBA), hydrogen bond donors (HBD), solubility $(\mathrm{mg} / \mathrm{L})$, and number of rotatable bonds (NRB), were predicted for all the compounds. All of the derivatives showed good pharmacokinetic parameters for oral bioavailability (Table 3 ) and drug-likeness as contrived by "Lipinski's rule of 5".

\section{In silico docking studies}

Molecular docking studies were carried out for the synthesized analogs for investigating interactions of these compounds with PDE7 and understanding the mechanism of action of the designed molecules as PDE7 inhibitors. The docking procedure was validated by comparing the binding poses obtained by docking of reference inhibitor in the binding site of PDE7 with that of the original PDB. Most of the synthesized molecules showed appreciable binding with PDE7 as determined by analysing binding interactions and binding free energy $(\Delta \mathrm{G}$, $\mathrm{kcal} / \mathrm{mol}$ ) of the selected best docked poses (Table 4). Based on the lowest binding free energy and better docking interactions, the best docked poses of all the synthesized compounds (S1-S6) were further analyzed in details by PyMOL and Biovia Discovery Studio (Dassault Systems).

The overlay pictures of all the synthesized compounds (S1-S6) with the PDB Ligand 4PM0 (2-(cyclopentylamino)-3ethyl-7-ethynylthieno[3,2-d]pyrimidin-4(3H)-one) showed that these compounds have the similar orientation and binding pattern in the binding site of PDE7 protein as that of the co-crystallized inhibitor of PDE7 (Figure 2).

The docked pose of S2 showed various types of hydrophobic interactions including pi-pi (Tyr211 and Phe416), pisigma (Val380), pi-alkyl (Ile323 and Ile363), and alkyl (Pro262). Compound $\mathrm{S} 2$ showed two $\mathrm{H}$-bond interactions between $\mathrm{OH}$ group of compound S2 and hydroxyl moiety of Tyr211 and carbonyl of ASn365 residues of PDE7 protein with bond length of 3.10 and 2.72 $\AA$, respectively. The "4-hydroxyphenyl" ring of S2 protruded in the hydrophobic pocket showed interactions with Tyr211, Val380, and Phe416 residues in binding site of PDE7. The "1,2-dihydropyrazol-

Table 2. ${ }^{1} \mathrm{H}-\mathrm{NMR}$ and FTIR spectral data for the synthesized compounds (S1-S6).

\begin{tabular}{|c|c|c|}
\hline Comp. & ${ }^{1} \mathrm{H}-\mathrm{NMR}(\delta)$ & FTIR vmax $\left(\mathrm{cm}^{-1}\right)$ \\
\hline S1 & $2.5006,3.1625,7.4475-7.4295,7.5193-7.5402,7.7066-7.7276,9.7021$ & $1,073,1,370,1,462,1,640,2,856-2,973$ \\
\hline S2 & $2.4919,3.2028,6.8180-6.7968,7.3406-7.3753,7.4281-7.4368,7.6375-7.6163,8.7534,9.5886$ & $1,290,1,420,1,458,1,651,2,934-2,972,3,420$ \\
\hline S3 & $2.5291,3.2421,7.3497-7.3990,7.4863-7.4907,7.9676-7.9896,8.2401-8.2620,9.7915$ & $\begin{array}{c}1,345,1,552,1,418,1,460,1,642,2,851-2,926, \\
3,075-3,107\end{array}$ \\
\hline S4 & $2.4979,3.1592,3.8909,3.9202,7.1234,7.4013-7.4258,7.4659-7.5047,9.6862$ & $1,234,1,393,1,464,1,647,2,846-2,942$ \\
\hline S5 & $2.5186,3.2605,6.9239-6.9334,7.3753-7.3996,7.4896-7.5283,9.8619$ & $1,365,1,467,1,642,2,944-3,150$ \\
\hline S6 & $\begin{array}{c}2.4856,3.1317,3.9182,3.9426,6.9684-6.9888,7.3013-7.3268,7.4003-7.4249,7.4536-7.4688, \\
7.5481-7.5525,9.6945\end{array}$ & $1,268,1,364,1,461,1,646,2,841-3,081$ \\
\hline
\end{tabular}

Table 3. Predicted ADME properties of the synthesized compounds (S1-S6).

\begin{tabular}{|c|c|c|c|c|c|c|c|c|c|}
\hline Comp. & MW & $\log P$ & $\log D$ & $\log S w$ & tPSA & HBA & HBD & Solubility & NRB \\
\hline S1 & 370.2 & 2.81 & 3.65 & -4.03 & 39.3 & 4 & 0 & $6,578.4$ & 3 \\
\hline S2 & 307.4 & 1.77 & 2.57 & -2.98 & 59.5 & 5 & 1 & $15,655.6$ & 3 \\
\hline S3 & 336.3 & 1.95 & 2.82 & -3.20 & 85.1 & 7 & 0 & $13,755.8$ & 4 \\
\hline S4 & 381.4 & 2.03 & 2.41 & -3.33 & 66.9 & 7 & 0 & $13,592.4$ & 6 \\
\hline S5 & 326.3 & 3.06 & 1.97 & -3.84 & 98.3 & 8 & 0 & $7,024.2$ & 4 \\
\hline
\end{tabular}

Table 4. Binding interactions and docking score $(\Delta \mathrm{G})$ of the synthesized derivatives with PDE7.

\begin{tabular}{|c|c|c|c|c|}
\hline \multirow{2}{*}{ Comp. } & \multicolumn{2}{|c|}{ H-bond interactions } & \multirow{2}{*}{ Residues involved in hydrophobic interactions } & \multirow{2}{*}{$\Delta \mathbf{G}$} \\
\hline & Residues & Distance ( $\AA$ ) & & \\
\hline S1 & $\mathrm{NI}^{\mathrm{a}}$ & $\mathrm{NI}^{*}$ & Tyr211, Pro262, Ile323, Ile363, Val380, Phe416 & -7.5 \\
\hline \multirow{2}{*}{ S2 } & Tyr211 & 3.10 & \multirow{2}{*}{ Tyr211, Ile323, Ile363, Val380, Phe384, Phe416 } & \multirow{2}{*}{-8.} \\
\hline & Asn365 & 2.72 & & \\
\hline S3 & Tyr211 & 3.03 & Ile323, Ile363, Val380, Phe384, Phe416 & -8.5 \\
\hline S5 & $\mathrm{G} \ln 413$ & 3.15 & Tyr211, His216, Val380, Phe416 & -8.8 \\
\hline S6 & $\mathrm{G} \ln 413$ & $2.96,3.22$ & Tyr211, His 212, His216, Ile323, Val380, Phe416 & -9.5 \\
\hline Control $^{\mathrm{b}}$ & $\mathrm{G} \ln 413$ & 3.34 & Tyr211, His216, Ile323, Val380, Phe416 & -7.9 \\
\hline
\end{tabular}

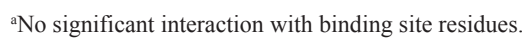

${ }^{\mathrm{b} C}$ Control: Co-crystallized PDE7 inhibitor (2-(cyclopentylamino)-3-ethyl-7-ethynylthieno[3,2-d]pyrimidin-4(3H)-one) (PDB ID: 4PM0). 

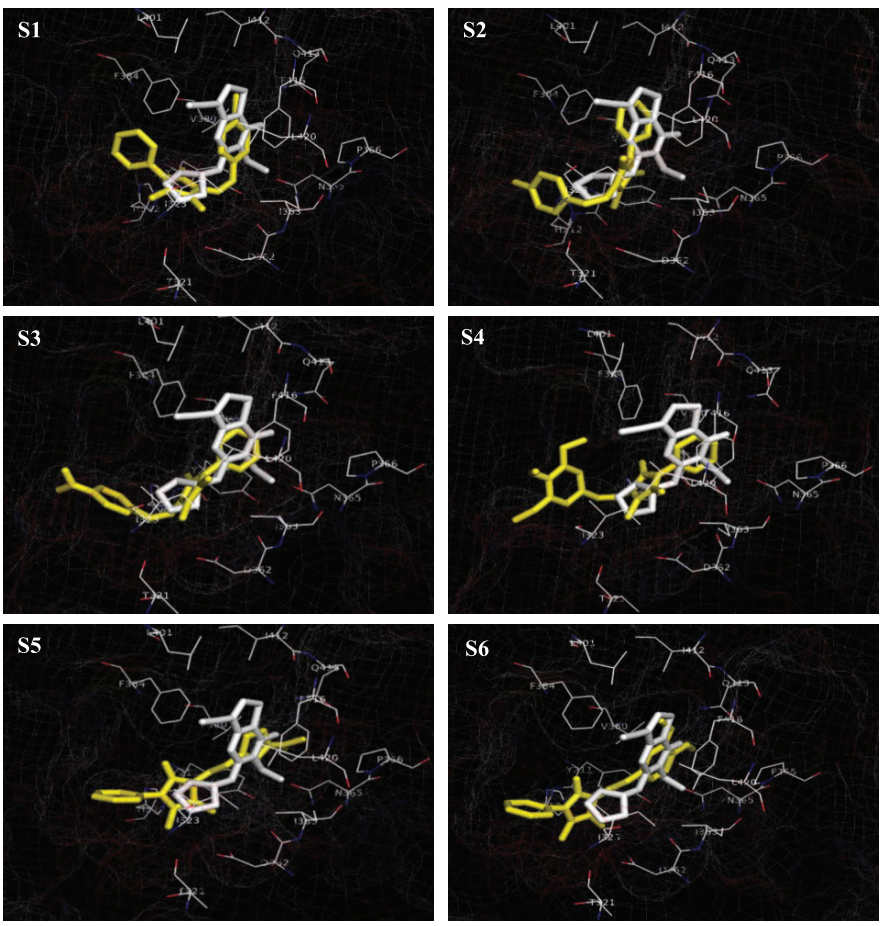

Figure 2. Orientation and overlay of the docked poses of the synthesized compounds (S1-S6) (yellow sticks) with that of PDB ligand 4PM0 (white sticks) in the binding site of PDE7.
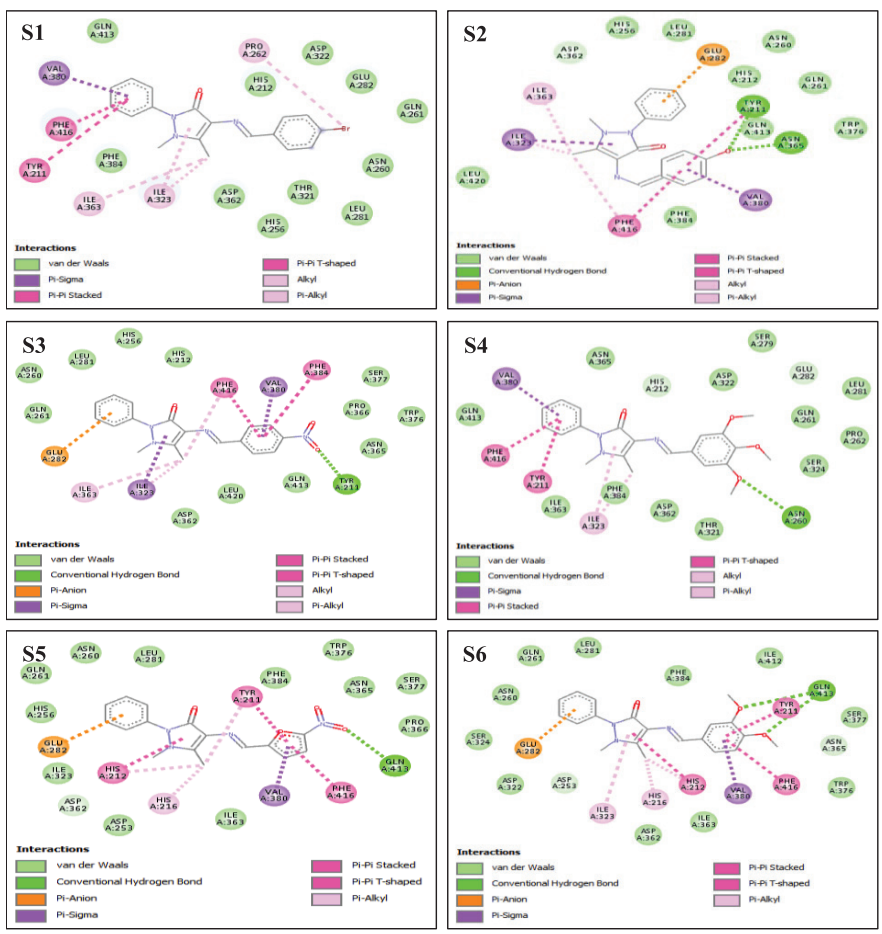

Figure 3. Docked poses showing various types of binding interactions, including H-bond and hydrophobic interactions of the synthesized compounds (S1-S6) with the binding site residues of PDE7 protein.

3-one" ring of S2 showed hydrophobic interactions with Ile323 and Ile363 residues in the binding site of PDE7. S3 showed one H-bond with Tyr211 residue of PDE7 enzyme with bond length of $3.03 \AA$. S4 formed one H-bond with Asn260 residue of PDE7 enzyme with bond length of $3.16 \AA$. Compound S5 showed one H-bond Gln413 residue of PDE7 enzyme with bond length of 3.15 Å. S6 showed two H-bond interactions between -O- group and $\mathrm{NH}$ group of Gln413 residue of PDE7 protein with bond length of 2.96 and $3.22 \AA$, respectively. The "3,4-dimethoxyphenyl" ring of S6 protruded in hydrophobic pocket showing interactions with Tyr211, Val380, and Phe416 residues in binding site of PDE7. The "1,2-dihydropyrazol-3-one" ring of S6 showed hydrophobic interactions with His 212, His216, and Ile323 residues and "phenyl" ring showed hydrophobic interactions with Glu282 residue (Figure 3). Thus, molecular docking studies carried out on the synthesized molecules helped us in predicting that these compounds possess stable and significant H-bonds and hydrophobic interactions with PDE7 protein, expecting that these synthesized molecules could act as potent inhibitors of PDE7.

\section{CONCLUSION}

Schiff bases of 4-aminopyrazone have a deep impact in medicinal chemistry. Since many years, these bases have been synthesized and have been evaluated for various pharmacological activities against a wide range of targets. This research paper mentions the synthesis of Schiff bases by an efficient methods, i.e., grinding technique, which were characterized on the basis of melting point, FTIR, and NMR spectroscopy. All the synthesized molecules showed appreciable docking interactions with binding site residues of the PDE7 protein and good ADME properties for oral bioavalability.

\section{ACKNOWLEDGMENT}

The authors are thankful to Chitkara University for providing financial support and research facilities. They are also thankful to Mr. Rajesh for helping in carrying out IR spectras at Chitkara University and Mr. Avtar Singh, SAIF, Panjab University Chandigarh, for providing help in undertaking NMR.

Author Contributions: All authors made substantial contributions to conception and design, acquisition of data, or analysis and interpretation of data; took part in drafting the article or revising it critically for important intellectual content; agreed to submit to the current journal; gave final approval of the version to be published; and agree to be accountable for all aspects of the work. All the authors are eligible to be an author as per the international committee of medical journal editors (ICMJE) requirements/guidelines.

\section{FUNDING}

There is no funding to report.

\section{CONFLICTS OF INTEREST}

The authors report no financial or any other conflicts of interest in this work.

\section{ETHICAL APPROVALS}

This study does not involve experiments on animals or human subjects.

\section{PUBLISHER'S NOTE:}

This journal remains neutral with regard to jurisdictional claims in published institutional affiliation. 


\section{REFERENCES}

Aboul-Fadl T, Bin-Jubair FAS. Anti-tubercular activity of isatin derivatives. Int J Res Pharm Sci, 2010; 1(2):113-26.

Akhter S, Zaman HU, Mir S, Dar AM, Shrivastava S. Synthesis of Schiff base metal complexes: a concise review. Eur Chem Bull, 2017; $6(10): 475-83$.

Alam MS, Choi JH, Lee DU. Synthesis of novel Schiff base analogues of 4-amino-1,5-dimethyl-2-phenylpyrazol-3-one and their evaluation for antioxidant and anti-inflammatory activity. Bioorg Med Chem, 2012; 20:4103-8.

Al Zoubi W, Al-Hamdani AAS, Kaseem M. Synthesis and antioxidant activities of Schiff bases and their complexes: a review. Appl Organometal Chem, 2016; 30:810-17.

Barnes MJ, Cooper N, Davenport RJ, Dyke HJ, Galleway FP, Galvin FC, Gowers L, Haughan AF, Lowe C, Meissner JW, Montana JG, Morgan T, Picken CL, Watson RJ. Synthesis and structure-activity relationships of guanine analogues as phosphodiesterase 7 (PDE7) inhibitors. Bioorg Med Chem Lett, 2001; 11:1081-3.

Charaya N, Pandita D, Grewal AS, Lather V. Design, synthesis and biological evaluation of novel thiazol-2-yl benzamide derivatives as glucokinase activators. Comput Biol Chem, 2018; 73:221-29.

Cunha S, Oliveira SM, Rodrigues MT Jr., Bastos RM, Ferrari J, de Oliveira CMA, Kato L, Napolitano HB, Vencato I, Lariucci C. Structural studies of 4-aminoantipyrine derivatives. J Mol Struct, 2005; 752:32-9.

da Silva CM, da Silva DL, Modolo LV, Rosemeire BA, Alves Resende B, de Resende MA, Martins CVB, de Fatima A. Schiff bases: A short review of their antimicrobial activities. J Adv Res, 2011; 2(1):1-8.

Gaber M, El-Ghamry HA, Fathalla SK, Mansour MA. Synthesis, spectroscopic, thermal and molecular modeling studies of $\mathrm{Zn}^{2+}, \mathrm{Cd}^{2+}$ and $\mathrm{UO}_{2}{ }^{2+}$ complexes of Schiff bases containing triazole moiety. Antimicrobial, anticancer, antioxidant and DNA binding studies. Mater Sci Eng C Mater Biol Appl, 2018; 83:78-89.

Gil C, Campillo NE, Perez DI, Martinez A. PDE7 inhibitors as new drugs for neurological and infl ammatory disorders. Expert Opin Ther Patents, 2008; 18(10):1127-39.

Grewal AS, Sharma N, Singh S, Arora S. In silico designing of novel thiazolidine-2-one derivatives as dual PDE4/7 inhibitors for inflammatory disorders. J Pharm Technol Res Mgmt, 2017a; 5(2):149-62.

Grewal AS, Kumar P, Dua JS, Lather V. Synthesis, docking and anti-inflammatory activity of some newer triazole derivatives as potential PDE7 inhibitors. J Med Chem Toxicol, 2017b; 2(2):55-61.

Hörl WH. Nonsteroidal Anti-Inflammatory Drugs and the Kidney. Pharmaceuticals, 2010; 3:2291-321.

Jawher V, Al-Baytii NS, Alshirayda HAY. Synthesis, spectroscopic and antibacterial investigation of new molecular hybridized 4-aminoantipyrine derivatives of pharmaceutical interest. Tikrit J Pharm Sci, 2011; 7(2):152-61.

Lagorce D, Bouslama L, Becot J, Miteva MA, Villoutreix BO. FAF-Drugs4: Free ADME-Tox filtering computations for chemical biology and early stages drug discovery. Bioinformatics, 2017; 33:3658-60.

Lorthiois E, Bernardelli P, Vergne F, Oliveira C, Mafroud AK, Proust E, Heuze L, Moreau F, Idrissi M, Tertre A, Bertin B, Coupe M, Wrigglesworth R, Descours A, Soulard P, Berna P. Spiroquinazolinones as novel, potent, and selective PDE7 inhibitors. Part 1. Bioorg Med Chem Lett, 2004; $14: 4623-6$

Malik MA, Dar OA, Gull P, Wani MY, Hashmi AA. Heterocyclic Schiff base transition metal complexes in antimicrobial and anticancer chemotherapy. Med ChemComm, 2018; 9(3):409-36.
Miteva MA, Guyon F, Tufféry P. Frog2: Efficient 3D conformation ensemble generator for small compounds. Nucleic Acids Res, 2010; 38:W622-7.

Mohanram I, and Meshram J. Synthesis and biological activities of 4-aminoantipyrine derivatives derived from Betti-type reaction. ISRN Org Chem 2014; 2014:639392.

Morris GM., Huey R, Lindstrom W, Sanner MF, Belew RK, Goodsell, DS, Olson AJ. Autodock4 and AutoDockTools4: automated docking with selective receptor flexibility. J Comput Chem, 2009; 16: 2785-91.

Murtaza S, Akhtar MS, Kanwal F, Abbas A, Ashiq S, Shamim S. Synthesis and biological evaluation of schiff bases of 4-aminophenazone as an anti-inflammatory, analgesic and antipyretic agent. J Saudi Chem Soc, 2017; 21:S359-72.

Rainsford KD. Anti-inflammatory drugs in the 21 st century. In: Harris RE (ed.). Inflammation in the pathogenesis of chronic diseases: the COX-2 controversy. Springer, Dordrecht, The Netherlands, pp 3-27, 2007.

Rakesh KP, Manukumar HM, Gowda DC. Schiff's bases of quinazolinone derivatives: synthesis and SAR studies of a novel series of potential anti-inflammatory and antioxidants. Bioorg Med Chem Lett, 2015; 25(5):1072-7.

Redondo M, Brea J, Perez DI, Soteras I, Val C, Perez C, MoralesGarcía JA, Alonso-Gil S, Paul-Fernandez N, Martin-Alvarez R, Cadavid MI, Loza MI, Perez-Castillo A, Mengod G, Campillo NE, Martinez A, Gil C. Effect of phosphodiesterase 7 (PDE7) inhibitors in experimental autoimmune encephalomyelitis mice. Discovery of a new chemically diverse family of compounds. J Med Chem, 2012; 55:3274-84.

Sharma H, Lather V, Grewal AS, Pandita D. Synthesis, antiinflammatory activity and docking studies of some newer 1,3-thiazolidine2,4-dione derivatives as dual inhibitors of PDE4 and PDE7. Curr ComputAid Drug Des, 2019; 15(3):225-34.

Sondhi SM, Singh N, Kumar A, Lozach O, Meijer L. Synthesis, anti-inflammatory, analgesic and kinase (CDK-1,CDK-5 and GSK-3) inhibition activity evaluation of benzimidazole/benzoxazole derivatives and some Schiff's bases. Bioorg Med Chem, 2006; 14:3758-65.

Trott O, Olson AJ AutoDock Vina: improving the speed and accuracy of docking with a new scoring function, efficient optimization and multithreading. J Comput Chem, 2010; 31:455-61.

Vergne F, Bernardelli P, Lorthiois E, Pham N, Proust E, Oliveira C, Mafroud AK, Royer F, Wrigglesworth R, Schellhaas J, Barvian M, Moreau F, Idrissi M, Tertre A, Bertin B, Coupe M, Berna P, Soulard P. Discovery of thiadiazoles as a novel structural class of potent and selective PDE7 inhibitors. Part 1: design, synthesis and structure-activity relationship studies. Bioorg Med Chem Lett, 2004; 14:4607-13.

How to cite this article:

Arora R, Sharma R, Tageza A, Grewal AS, Saini B, Arora $\mathrm{S}$, Kaur R. Design and synthesis of novel 4-aminophenazone Schiff bases by grinding technique as prospective antiinflammatory agents. J Appl Pharm Sci, 2021; 11 (Supp 1): 048-053. 